\title{
Estimated rate of karst aquifer development by MRC analysis and flood hydrograph components at Guntur Springs, Gunungsewu Karst Area, Indonesia
}

\author{
Muhammad Naufal", Tjahyo Nugroho Adji, Ahmad Cahyadi, Eko Haryono, Margaretha Widyastuti, Indra Agus \\ Riyanto, and Fajri Ramadhan
}

Karst Research Group, Faculty of Geography, Universitas Gadjah Mada, Indonesia

\begin{abstract}
Understanding the stage of karst aquifer development (karstification) is of vital importance because this parameter can reflect the character of flow system release, from which relevant management patterns are derived. Master Recession Curve (MRC) construction is considered ideal for identifying at which stage karstification works because MRC relies on recession curves as its primary input. Recession curves are the most stable component of flow hydrographs in representing aquifer characteristics. The study focused on springs located in a karst hydrogeological subsystem, namely, Guntur Spring in the Panggang Hydrogeological Subsystem (Gunungsewu Karst Area). It was designed to determine (1) the flow characteristics and (2) the degree of karst aquifer development at Guntur Spring. It utilized a one-year flow hydrograph with a 30-minute logging interval as the main data. The flood hydrograph showed that a fissure system dominated the flow characteristics. Moreover, the MRC construction results indicated that the karstification level at Guntur Spring was 5.0, confirming the dominant fissure system and also signs of the recent development of conduit flows.
\end{abstract}

\section{Introduction}

The rate of karst aquifer development (karstification) can reflect in what manner the aquifer releases its flow. Various approaches have been adopted to classify this level, including (1) hydrogeochemical analysis, by monitoring variations in the levels of chemical elements dissolved in karst springs or rivers, (2) linear system analysis, (3) heterogeneity ratios, (4) recession analysis of flood hydrographs, and (5) aquifer flashiness.

Quinland et al. [1] states that analyzing the recession of flood hydrographs can acquire flow characteristics that are more representative of conduit developments in a karst aquifer. Also, using the outlet of a karst system, or spring, for the same analysis is a method commonly used to characterize karst aquifers [2]. Despite its simplicity, this method can sufficiently describe the characteristics of karst aquifers in releasing their flows and indirectly determine the rate of development of their tunneling [3]. Nevertheless, the use of a single recession curve in many previous flood hydrograph studies shows a disadvantage; that is, varying recession curves in every flood event. Consequently, Malik and Vojtkova [4] has introduced the concept of the Master Recession Curve (MRC) to calculate the karstification degree (rate of development) of karst aquifers in the catchments of two adjacent springs. MRC combines several single recession curves by the matching strip method [5]. Furthermore, Arnold et al. [6] has enabled automatic
MRC reconstruction with digital computing, and the calculation shows an accuracy of $74 \%$.

The study focused on Guntur Spring. It emerges from the Panggang Hydrogeological Subsystem Zone, which is situated in the westernmost part of a larger hydrogeological unit, Gunungsewu Karst Area. This part is typified by shallow, horizontal volcaniclastic sedimentary rocks. Administratively, the spring is in Dringo Sub-village, Girijati Village, Purwosari District, Gunungkidul Regency (Figure 1). Based on current conditions, the local community can use its water flow for irrigation throughout the year and even domestic purposes, especially in the dry season.

Given the substantial benefits of springs, research characterizing the stage of karst aquifer development becomes necessary. This research was intended to (1) identify the flow characteristics and (2) the rate of karst aquifer development at Guntur Spring.

\section{Methodology}

The main research data was a one-year flow hydrograph recorded every $30 \mathrm{~min}$ at Guntur Spring using a Hobo U30 Automatic Water Level Logger. The flow discharge used for generating the rating curve and flow hydrograph was measured directly for 30 times buoys and current meters (the velocity area method). Then, the components of the flood hydrograph were analyzed, and the MRC was calculated to characterize the aquifers of Guntur Spring.

\footnotetext{
* Corresponding author: adji@geo.ugm.ac.id
} 


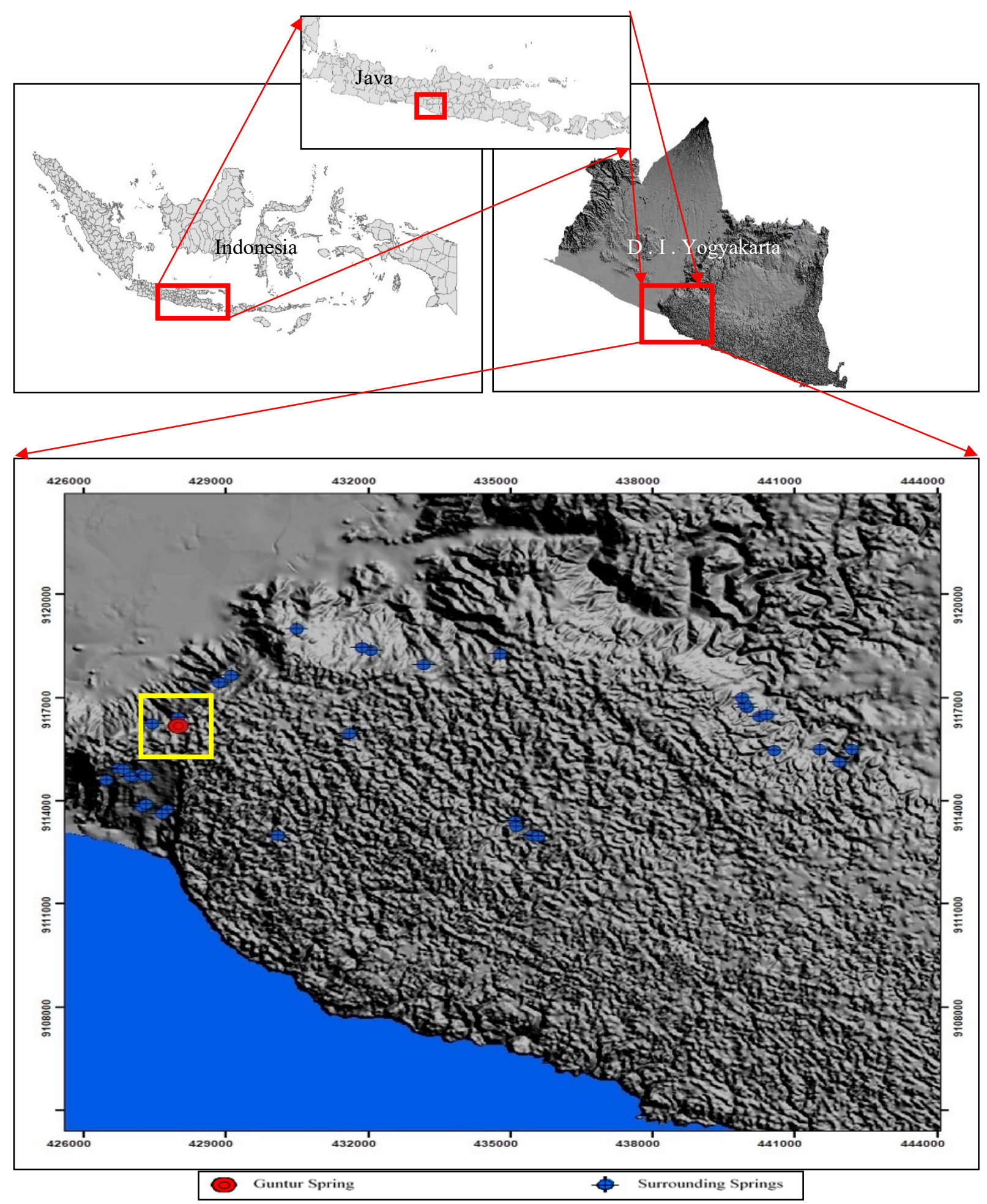

Fig. 1. The research location at Guntur Spring in the Panggang Hydrogeological Subsystem Zone, part of Gunungsewu Karst Area 


\subsection{Flood hydrograph}

A flood hydrograph consists of time to peak (Tp), peak discharge (Qp), and time to baseflow (Tb) (Figure 3). It can indicate the characteristics of a karst aquifer because its shape or components reflect the condition of the catchment area, the size of the storage, and how the flow is released [7].

\subsection{MRC construction}

In the RC 4.0 program, the MRC was constructed semiautomatically from a collection of recession curves selected from the flood hydrograph. Then, the MRC produced was used as a basis for determining the characteristics of every flow sub regime (Figure 4).

The type and number of flow sub-regimes in the MRC were determined using the Reynolds number. Nre $<20000$ indicates a laminar, and Nre $>2000$ indicates a turbulent flow [8]. The laminar and turbulent subregimes were calculated using Equation (1) [9] and Equation (2) [4, 10], respectively.

$$
\begin{gathered}
Q_{t}=Q_{0} \times e^{-\alpha t} \\
Q_{t}=Q_{0}(1-\beta t)
\end{gathered}
$$

The beta coefficient in Equation (2) was inputted to the equation below [11],

$$
\beta=\alpha\left(Q_{0}^{-\frac{1}{n}}\right)
$$

Coefficients $\mathrm{a}$ and $\mathrm{b}$ were inputted to the equation to determine the parameter values of the recession curve. Furthermore, the degree of karstification was deduced from the flow sub-regime coefficients using the classification of karst development proposed by Malik and Vojtkova [4] as a reference.

\section{Results and discussion}

\subsection{The flow characteristics of Guntur Spring}

The study was conducted at Guntur Spring for one year, starting from April of 2018 until the beginning of April of 2019. Instantaneous discharge and stage were measured 30 times in the field to create an equation describing their relationship, as presented by the rating curve in Figure 2. The $\mathrm{R}^{2}$ value of the rating curve was 0.9722 (closer to 1 ), meaning that the two components have a strong inter-correlation. Based on the yielded equation, $y=945.7 x+23.935$, the flow hydrograph of Guntur Spring is as presented in Figure 3.

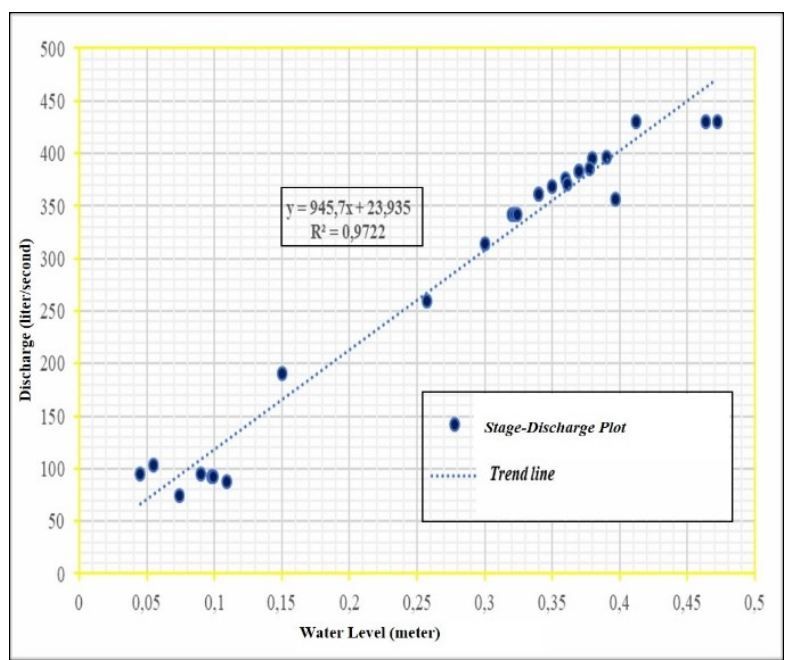

Fig. 2. The rating curve of Guntur Spring

During the time of the research, the smallest and largest discharges were $7.56 \mathrm{~L} \mathrm{~s}^{-1}$ and $504.23 \mathrm{~L} \mathrm{~s}^{-1}$, respectively, with an average of $169.14 \mathrm{~L} \mathrm{~s}^{-1}$. This relatively small average is one of the initial evidence that Guntur Spring emerges from the Panggang Hydrogeological Subsystem in Gunungsewu Karst Area [12]. Guntur Spring emerges from the top of the limestone bed, on which a thin water retention layer (epikarst) develops and results in the small quantity of groundwater storage [13]. This finding is consistent with Haryono et al. [12] and Haryono [14], which claim that springs coming out from the Panggang Hydrogeological Subsystem are predominantly epikarst springs. Furthermore, the averagely low discharge is influenced by the karst development factor, which, hypothetically, is at an early or low stage.

Based on the selected flood hydrographs (Table 1), the length of time required to reach the peak discharge (Tp) varied between $0.5 \mathrm{~h}$ to $30.16 \mathrm{~h}$, with an average of $8.68 \mathrm{~h}$, while the average duration of recession $(\mathrm{Tb})$ was $64.64 \mathrm{~h}$. The time to peak (Tp) reflects the long response of Guntur Spring to rain events in the recharge zone. In this context, the expected response is a rise in water discharge. As for the categorically long time to baseflow $(\mathrm{Tb})$, it demonstrates the slow recession or water release from the spring's system, confirming that fissures dominate the flow components. 


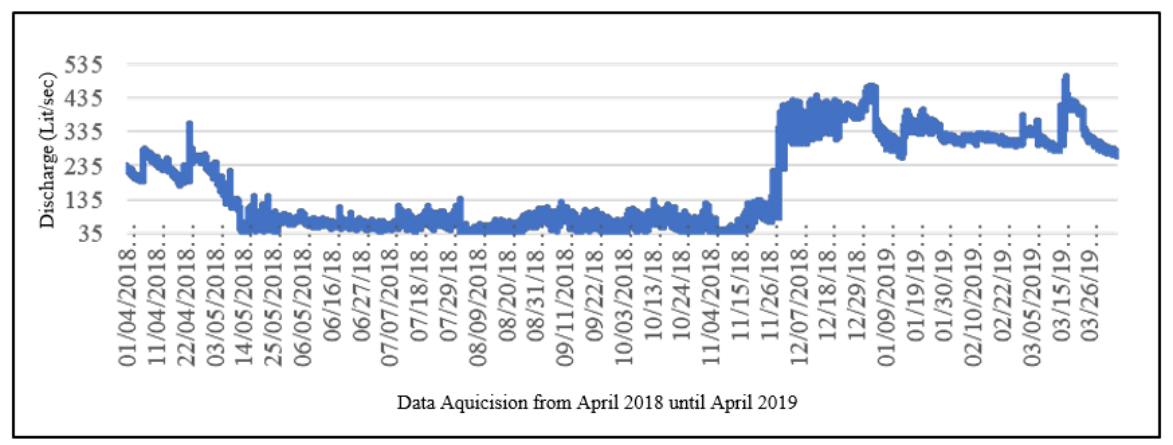

Fig. 3. The flow hydrograph of Guntur Spring

Table 1. Selected floods at Guntur Spring

\begin{tabular}{|c|c|c|c|c|c|c|}
\hline No. & Time & Hour & $\begin{array}{c}Q \\
\text { Max. (L/s) }\end{array}$ & Flood categories & Tp (hours) & Tb (hours) \\
\hline 1 & $04 / 07 / 2018$ & 10.00 & 279.56 & Moderate & 1.16 & 152.16 \\
\hline 2 & 05/08/2018 & 15.50 & 159.56 & Moderate & 30.16 & 13.16 \\
\hline 3 & $12 / 22 / 2018$ & 02.25 & 423.56 & High & 3.60 & 11 \\
\hline 4 & $01 / 23 / 2019$ & 02.25 & 402.56 & High & 14.50 & 27 \\
\hline 5 & 03/17/2019 & 00.00 & 504.23 & High & 2.16 & 106 \\
\hline 6 & $03 / 24 / 2019$ & 09.00 & 392.56 & High & 0.50 & 78.5 \\
\hline & & Mean & & & 8.68 & 64.64 \\
\hline
\end{tabular}

The calculated flood hydrographs components of Guntur Spring were compared with two other springs located in Gunungsewu Karst, as presented in Table 2. Beton Spring is an outlet of a developed karst system recharged by many sinking streams [15] and is part of the Ponjong Hydrogeological Subsystem Zone. Meanwhile, Petoyan is a karst spring dominated by diffuse fracture systems [16], and, similar to Guntur Spring, it is located in the Panggang Hydrogeological Subsystem Zone.

Table 2. Comparison between the flow characteristics of Guntur Spring and two other karst springs

\begin{tabular}{cccc}
\hline Characteristics & Guntur & Beton & Petoyan \\
\hline $\mathrm{Q}_{\mathrm{p}}(\mathrm{L} / \mathrm{s})$ & 504.23 & 4948.98 & 158.72 \\
$\mathrm{~T}_{\mathrm{p}}$ (hours) & 2.16 & 2 & 25 \\
$\mathrm{~T}_{\mathrm{b}}$ (hours) & 106 & 22.83 & 86.5 \\
\hline
\end{tabular}

Guntur Spring has the second-largest $Q_{p}$ (followed by Beton Spring) and $T_{p}$ that is almost as fast as Beton Spring. This finding illustrates that the karst aquifer supplying water to Guntur Spring has an already developed conduit fracture system. Meanwhile, the time to baseflow of Guntur Spring is categorically slow $\left(T_{b}=105 \mathrm{~h}\right)$ and similar to that of Petoyan Spring but with a much higher $Q_{p}$. For these reasons, the karst aquifer of Guntur Spring is considered reliable in storing groundwater.

\subsection{Karst aquifer development stage}

\subsubsection{The MRC construction of Guntur Spring's aquifer}

The degree of karst aquifer development at Guntur Spring was identified using eight (8) single recession curves. After automatically processing and combining these curves, the generated MRC showed that the spring had one laminar flow and one turbulent flow (Figure 4). Laminar indicates the release of the diffuse flow component, as marked by the gently sloping curve (a slower discharge process). On the contrary, turbulent reflects the discharge of conduit and fissure flows, as evidenced by a steeper decline in the curve-or, in other words, a faster discharge process. The MRC of Guntur Spring produced the equation $\mathrm{Qt}=0.35-\mathrm{e}^{-0.002 \mathrm{t}}+0.07$ $-(1-0.02 t)$. Based on the MRC, the turbulent flow discharge is depicted by a sloping curve because it flows through fractures or cavities that have not fully developed or karstified yet and, consequently, its release requires a longer time. The length of time needed to release the turbulent flow component was up to 50 hours, while that of diffuse flow (laminar) started afterward.

\subsubsection{Aquifer Development at Guntur Spring}

The MRC equation of Guntur Spring is $\mathrm{Qt}=0.35-\mathrm{e}-$ $0.002 t+0.07-(1-0.02 t)$. It consists of one simple 
exponential (with a recession type of linear reservoir) and one simple linear turbulent equation (with a recession type of turbulent flow). Based on the classification introduced by Malik and Vojtkova [4], the equation illustrates that the degree of karstification of Guntur Spring's aquifer system is 5.0. At this degree, diffuse and fissure dominate the fractures, and conduit networks begin to influence the flow system.

The dominant diffuse flow at Guntur Spring indicates that the underlying karst aquifer is reliable groundwater storage, as evidenced by the relatively slow time to baseflow $(\mathrm{Tb}=64.64 \mathrm{~h})$. Guntur Spring never dries up throughout the year, which confirms this finding.

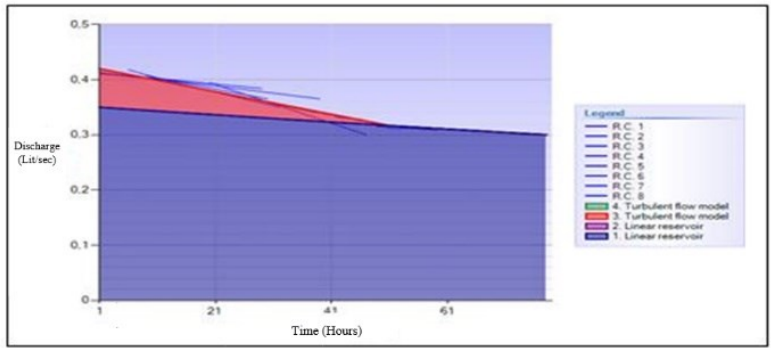

Fig. 4. The construction of the Master Recession Curve

As for the development of conduit networks, it can be determined by some evidence identified in the field, such as the dynamic changes in water's color and the development of karst features around the spring. Through observations, the research found that the color of the spring water became increasingly muddy during the rainy season even though this change did not always follow every rain event and, when it did, could take form long after the rain. In other words, the change in water turbidity depends on rainfall intensity. Water turbidity itself is an indicator of developed and currently developing karst regions. Based on the tracer test results of previous studies underground rivers, which recharge Guntur Spring, also show the initial development of conduits in the karst aquifer system.

\section{Conclusion}

During the time of the research, Guntur Spring produces $7.56 \mathrm{~L} \mathrm{~s}^{-1}$ (smallest) and $504.23 \mathrm{~L} \mathrm{~s}^{-1}$ of water (largest). The relatively small discharge is one of the initial evidence that Guntur Spring emerges from the Panggang Hydrogeological Sub-system in Gunungsewu Karst. The length of time required to reach the peak discharge $(\mathrm{Tp})$ is averagely $8.68 \mathrm{~h}$, while the average duration of recession $(\mathrm{Tb})$ is $64.64 \mathrm{~h}$. These conditions confirm that fissures dominate the flow system.

The MRC equation of Guntur Spring is $\mathrm{Qt}=0.35-$ $\mathrm{e}^{-0.002 t}+0.07-(1-0.02 t)$. It consists of one simple exponential (with a recession type of linear reservoir) and one simple linear turbulent equation (with a recession type of turbulent flow). Based on the classification introduced by Malik and Vojtkova, the equation illustrates that the degree of karstification of Guntur Spring's aquifer system is 5.0. At this degree, diffuse and fissure dominate the fractures, and conduit networks begin to influence the flow system. In other words, the spring has one laminar flow and one turbulent flow.

\section{References}

1. J.F. Quinlan, P.L. Smart, G.M. Schindel, E.C. Alexander, A.J. Edwards, A.R. Smith, Recommended administrative/regulatory definitions of karst aquifer. Principles for classification of carbonate aquifers. Practical evaluation of vulnerability of karst aquifers a determination of optimum sampling frequency at springs. In: Quinlan JF, Stanley A (eds), Hydrology, ecology, monitoring and management of groundwater in karst terraces conference, 3rd, Proceedings: Dublin, Ohio, National Ground Water Association, pp 573-635 (1991)

2. D. Ford, P. Williams, The Geographical Journal, 157 (1988)

3. O. Bonacci, Hydrological Sciences 38,1:51-62 (1993)

4. P. Malik, S. Vojtkova, Environ Earth Sci, 65: 22452257(2012)

5. F. Snyder, Eos Trans. AGU, 20:25-738(1939)

6. J.G. Arnold, P.M. Allen, R. Muttiah, G. Bernhardt, Groundwater 33 1010-1018 (1995)

7. T.N. Adji, E. Haryono, A. Mujib, H. Fatchurohman, I.Y. Bahtiar, Carbonates and Evaporites, 34,1:5366 (2019).

8. D.C. Ford, P.W. Williams, Karst Hydrogeology and Geomorphology, Chichester: Wiley (2007)

9. E. Maillet, e Hermann Paris, 218 (1905)

10. E. Kullman, Podzemna voda, 6:31-41 (2000)

11. F. Fiorillo, Water Resour Manage, 28:1781-1805 (2014). DOI 10.1007/s11269-014-0597-z.

12. E. Haryono, D. Barianto, A.H. Cahyadi, Panduan Kegiatan Lapangan Hidrogeologi Kawasan Karst Gunung Sewu. Yogyakarta: PIT-PAAI (2017)

13. A. Cahyadi, I. Riyanto, M. R. Irshabdillah, F. Firizqi, Inventarisasi dan Karakterisasi Sistem Aliran Sungai Alogenik di Kawasan Karst Gunung Sewu Kabupaten Gunungkidul. Laporan Hibah Penelitian Dosen Fakultas Geografi UGM 2018. Yogyakarta: Fakultas Geografi Universitas Gadjah Mada (2018)

14. E. Haryono, Introduction to Gunung Sewu Karst. Field Guide of Asian Trans-Disciplinary Karst Conference. Yogyakarta: Karst Research Group, Faculty of Geography, Universitas Gadjah Mada (2011)

15. M. Naufal, Karakterisasi Perkembangan Akuifer Karst Gunung Sewu Melalui Analisis Master Recession Curve (MRC) (Studi Kasus Mataair Guntur Dan Mataair Beton Kabupaten Gunungkidul). Bachelor Thesis. Yogyakarta: Fakultas Geografi, Universitas Gadjah Mada (2019) [in Bahasa Indonesia]

16. T.N. Adji, I.Y. Bahtiar. Rainfall-discharge relationship and karst flow components analysis for 
karst aquifer characterization in Petoyan Spring, Java, Indonesia. DOI 10.1007/s12665-016-5553-1 (2016) 